\title{
Response of surface shortwave cloud radiative effect to greenhouse gases and aerosols and its impact on summer maximum temperature
}

\author{
Tao Tang ${ }^{1}$, Drew Shindell ${ }^{1}$, Yuqiang Zhang ${ }^{1}$, Apostolos Voulgarakis ${ }^{2}$, Jean-Francois Lamarque ${ }^{3}$, Gunnar Myhre ${ }^{4}$, \\ Camilla W. Stjern ${ }^{4}$, Gregory Faluvegi ${ }^{5,6}$, and Bjørn H. Samset ${ }^{4}$ \\ ${ }^{1}$ Division of Earth and Ocean Sciences, Duke University, Durham, NC, USA \\ ${ }^{2}$ Department of Physics, Imperial College London, London, UK \\ ${ }^{3}$ National Center for Atmospheric Research, Boulder, CO, USA \\ ${ }^{4}$ CICERO, Center for International Climate and Environment Research, Oslo, Norway \\ ${ }^{5}$ Center for Climate System Research, Columbia University, New York, NY, USA \\ ${ }^{6}$ NASA Goddard Institute for Space Studies, New York, NY, USA
}

Correspondence: Tao Tang (tao.tang@duke.edu)

Received: 18 December 2019 - Discussion started: 27 January 2020

Revised: 16 June 2020 - Accepted: 23 June 2020 - Published: 16 July 2020

\begin{abstract}
Shortwave cloud radiative effects (SWCREs), defined as the difference of the shortwave radiative flux between all-sky and clear-sky conditions at the surface, have been reported to play an important role in influencing the Earth's energy budget and temperature extremes. In this study, we employed a set of global climate models to examine the SWCRE responses to $\mathrm{CO}_{2}$, black carbon (BC) aerosols, and sulfate aerosols in boreal summer over the Northern Hemisphere. We found that $\mathrm{CO}_{2}$ causes positive SWCRE changes over most of the $\mathrm{NH}$, and BC causes similar positive responses over North America, Europe, and eastern China but negative SWCRE over India and tropical Africa. When normalized by effective radiative forcing, the SWCRE from $\mathrm{BC}$ is roughly 3-5 times larger than that from $\mathrm{CO}_{2}$. SWCRE change is mainly due to cloud cover changes resulting from changes in relative humidity $(\mathrm{RH})$ and, to a lesser extent, changes in cloud liquid water, circulation, dynamics, and stability. The SWCRE response to sulfate aerosols, however, is negligible compared to that for $\mathrm{CO}_{2}$ and $\mathrm{BC}$ because part of the radiation scattered by clouds under all-sky conditions will also be scattered by aerosols under clear-sky conditions. Using a multilinear regression model, it is found that mean daily maximum temperature $\left(T_{\max }\right)$ increases by 0.15 and $0.13 \mathrm{~K}$ per watt per square meter $\left(\mathrm{W} \mathrm{m}^{-2}\right)$ increase in local SWCRE under the $\mathrm{CO}_{2}$ and $\mathrm{BC}$ experiment, respectively. When domain-averaged, the contribution of SWCRE change to summer mean $T_{\max }$ changes was $10 \%-30 \%$ under $\mathrm{CO}_{2}$
\end{abstract}

forcing and $30 \%-50 \%$ under BC forcing, varying by region, which can have important implications for extreme climatic events and socioeconomic activities.

\section{Introduction}

Clouds have a pivotal role in influencing the Earth's energy budget (Ramanathan et al., 1989). By enhancing the planetary albedo, clouds exert a global mean shortwave cloud radiative effect (SWCRE) of about $-50 \mathrm{~W} \mathrm{~m}^{-2}$ at the top of the atmosphere, and by contributing to the greenhouse effect, they exert a mean longwave effect (LWCRE) of approximately $+30 \mathrm{~W} \mathrm{~m}^{-2}$ (Boucher et al., 2013). On the whole, clouds cause a net forcing of $-20 \mathrm{~W} \mathrm{~m}^{-2}$ relative to a cloudfree Earth, which is approximately 5 times as large as the radiative forcing from a doubling of the $\mathrm{CO}_{2}$ concentration. Therefore, a subtle change in cloud properties has the potential to cause significant impacts on climate (Boucher et al., 2013; Zelinka et al., 2017). Recent studies contended that the cloud feedback, especially the shortwave (SW) cloud feedback, is very likely to be positive (Clement et al., 2009; Dessler, 2010; Zelinka et al., 2017). As the SW cloud feedback is positively correlated with the net climate feedback parameter (Andrews et al., 2012, 2015; Zhou et al., 2016), a stronger positive SW cloud feedback will lead to higher climate sensitivity and may lead to a future warming towards 
the high end of current projections (Zhai et al., 2015; Andrews et al., 2018).

On seasonal scales, SWCRE is strongest in the summer months when the solar heating is strongest (Harrison et al., 1990). Because SWCRE is in effect only during daytime, it can substantially modify daily maximum temperature $\left(T_{\max }\right)$. For instance, Dai et al. (1999) found that increased cloud cover can reduce $T_{\max }$, thereby decreasing the diurnal temperature range. Tang and Leng (2012) reported that the damped $T_{\max }$ over Eurasia could be partially explained by the cloud cover increase during 1982-2009. As a positive feedback, SWCRE at the surface has also been reported to play a role in heat-wave and drought events over Europe by enhancing solar heating (Rowell and Jones, 2006; Vautard et al., 2007; Zampieri et al., 2009; Chiriaco et al., 2014; Myers et al., 2018). This has influenced the environment, ecosystems, and the economy by affecting the frequency and intensity of forest fires, power cuts, transport restrictions, crop failure, and loss of life (De Bono et al., 2004; Ciais et al., 2005; Robine et al., 2008). For example, Wetherald and Manabe (1995) reported that in the summer for midlatitude continents, higher temperature enhances evaporation in the spring and then evaporation decreases in the summer due to depleted soil moisture. Combined with higher temperature, this summertime evaporation reduction leads to lower relative humidity (RH), which reduces cloud cover and thereby invigorates solar heating. Cheruy et al. (2014) revealed that the inter-model spread of summer temperature projections in northern midlatitudes in CMIP5 (Climate Model Intercomparison Project Phase 5) models is greatly influenced by the SWCRE.

All the above studies suggest that the SWCRE plays an important role in influencing the surface energy budget and extreme temperature. Well-mixed greenhouse gases (WMGHGs) and aerosols are currently the two largest anthropogenic forcings (Myhre et al., 2013b). A better understanding of the climate response to these individual forcing agents is increasingly needed, considering their different trends across the globe and opposite impacts on climate (Shindell and Faluvegi, 2009). Due to the difficulty of separating the forced climate signal of a single agent within observational records, these studies are generally based on model simulations, such as the widely used quadrupling of $\mathrm{CO}_{2}$ experiments (Andrews et al., 2012). Many attempts have also been made to explore the aerosol impact on clouds and Earth's energy balance (Lohmann and Feichter, 2005; Chung and Soden, 2017), mean temperature (Ruckstuhl et al., 2008; Philipona et al., 2009), and extreme temperature (Sillmann et al., 2013; Xu et al., 2018). However, all these studies treated aerosols as a whole, and the individual impacts from absorbing and scattering aerosols are still less understood. Though some studies investigated the impact from individual aerosol species (Williams et al., 2001; Chuang et al., 2002; Koch and Del Genio, 2010), they generally used only a single model, and the results may be subject to model biases (Flato et al., 2013). Moreover, due to the continuing increase in the likelihood of hot temperature extremes (Seneviratne et al., 2014), as well as their serious consequences (De Bono et al., 2004), it is imperative to have a better understanding of the role of the SWCRE from individual forcing agents in hot extremes. However, a multi-model study on the cloud response to individual aerosol species and the impact of that response on $T_{\max }$ is still lacking. Given these knowledge gaps, here we investigate the changes in the SWCRE in response to $\mathrm{CO}_{2}, \mathrm{BC}$, and sulfate aerosols individually and explore the potential impact on $T_{\max }$ by using a set of state-of-the-art global climate models. $\mathrm{CO}_{2}$ is the most dominant WMGHG, while the latter two represent absorbing and scattering aerosols, respectively. This paper will proceed as follows: data and methods are described in Sect. 2. Results are presented in Sect. 3, and a discussion and summary are given in Sect. 4.

\section{Data and methods}

\subsection{Data}

This study employs the model output from groups participating in the Precipitation Driver and Response Model Intercomparison Project (PDRMIP), utilizing simulations examining the climate responses to individual climate drivers (Myhre et al., 2017). The nine models used in this study are CanESM2, GISS-E2R, HadGEM2, HadGEM3, MIROC, CESM-CAM4, CESM-CAM5, NorESM, and IPSL-CM5A. The versions of most models used in the PDRMIP are essentially the same as their CMIP5 versions. The configurations and basic settings are listed in Table 1. In these simulations, global-scale perturbations were applied to all the models: a doubling of the $\mathrm{CO}_{2}$ concentration $\left(\mathrm{CO}_{2} \times 2\right)$, a 10-fold increase in the present-day black carbon concentration and emissions $(\mathrm{BC} \times 10)$, and a fivefold increase in the present-day $\mathrm{SO}_{4}$ concentration and emissions $\left(\mathrm{SO}_{4} \times 5\right)$. All perturbations were abrupt. Each perturbation was run in two parallel configurations, a 15-year fixed sea surface temperature (fsst) simulation and a 100-year coupled simulation. One model (CESM-CAM4) used a slab ocean setup for the coupled simulation, whereas the others used a full dynamic ocean. $\mathrm{CO}_{2}$ was applied relative to the models' baseline values. For aerosol perturbations, monthly year 2000 concentrations were derived from the AeroCom Phase II initiative (Myhre et al., 2013a) and multiplied by the stated factors in concentration-driven models. Some models were unable to perform simulations with prescribed concentrations. These models multiplied emissions by these factors instead (Table 1). The aerosol loadings in the CanESM2 model for the two aerosol perturbations are shown in Fig. 1 for illustrative purposes; the spatial patterns are similar for other models. In the BC experiment, the concentration is highest in eastern China (E. China), followed by India and tropical 
Africa. For the $\mathrm{SO}_{4}$ simulations, the aerosols are mainly restricted to the Northern Hemisphere (NH), with the highest loading observed in E. China, followed by India and Europe. The eastern US also has moderately high concentrations. It is noted that only three of the nine models include aerosol-cloud interactions, while the remaining ones only have aerosol-radiation interactions. However, this does not impact our main conclusions (see Sect. 4). More detailed descriptions of PDRMIP and its initial findings are given in Samset et al. (2016), Myhre et al. (2017), Liu et al. (2018), and Tang et al. (2018).

\subsection{Methods}

In this study, we focus on the SWCRE at the surface in the low and midlatitudes during boreal summer months (JuneJuly-August, JJA hereafter), which is calculated as the difference in the SW radiative flux at the surface between allsky and clear-sky conditions (Ramanathan et al., 1989). The base state of SWCRE in each model is shown in Fig. S1, with a multi-model mean (MMM) value of $-57.9 \pm 1.8 \mathrm{~W} \mathrm{~m}^{-2}$ $(M M M \pm 1$ standard error). The spatial patterns are fairly consistent across the models, with strong SWCRE in tropical regions and middle to high latitudes and weaker SWCRE in the subtropics, which include regions with generally fewer clouds. Changes in SWCRE are obtained by subtracting the control simulations from the perturbations using the data of the last 20 years in each coupled simulation. The changes are then normalized by the effective radiative forcing (ERF) in the corresponding experiments to obtain the changes per unit global forcing for comparison. Previous studies demonstrated that climate changes linearly with climate forcing for various forcing agents, including BC (Hansen et al., 2005; Mahajan et al., 2013). The ERF values for each model are obtained from Tang et al. (2019), who diagnosed those from the data for years 6-15 of the fsst simulations from each perturbation by calculating the radiative flux changes at the top of the atmosphere (Hansen et al., 2002). The MMM ERF values are $3.65 \pm 0.09 \mathrm{~W} \mathrm{~m}^{-2}\left(\mathrm{CO}_{2} \times 2\right), 1.16 \pm 0.25 \mathrm{~W} \mathrm{~m}^{-2}$ $(\mathrm{BC} \times 10)$, and $-3.52 \pm 0.63 \mathrm{Wm}^{-2}\left(\mathrm{SO}_{4} \times 5\right)$ for the indicated experiments (MMM \pm 1 standard error). The MMM changes are estimated by averaging all nine model results, giving the same weighting factor to each model. A two-sided Student's $t$ test is used to examine whether the MMM results are significantly different from zero. The same process was also repeated for other variables analyzed (i.e., temperature and humidity).

In order to investigate the impact of circulation changes on specific humidity, following Banacos and Schultz (2005), the horizontal moisture flux convergence (MFC) is calculated as

$\mathrm{MFC}=-\nabla \cdot(q V)=-V \cdot \nabla q-q \nabla \cdot V$.

In Eq. (1), $q$ is specific humidity $\left(\mathrm{g} \mathrm{kg}^{-1}\right)$, and $V$ is horizontal wind including both zonal and meridional components. All variables have a monthly temporal resolution. Equation (1) could be further written as

$\mathrm{MFC}=-u \frac{\partial q}{\partial x}-v \frac{\partial q}{\partial y}-q\left(\frac{\partial u}{\partial x}+\frac{\partial v}{\partial y}\right)$,

in which $u$ and $v$ are zonal and meridional wind components $\left(\mathrm{ms} \mathrm{s}^{-1}\right)$.

\section{Results}

\subsection{SWCRE change}

Figure 2a-c show the SWCRE changes in response to abrupt changes in $\mathrm{CO}_{2}, \mathrm{BC}$, and $\mathrm{SO}_{4} . \mathrm{CO}_{2}$ causes positive changes in SWCRE over most areas in the $\mathrm{NH}$, indicating that more $\mathrm{SW}$ radiation reaches the surface. $\mathrm{BC}$ causes similar changes but with enhanced (ERF-normalized) magnitude, especially in North America (N. America), Europe, and East Asia (E. Asia). In some source regions of BC aerosols (tropical Africa and India), however, the SWCRE changes are negative, which means more SW is reflected. These changes are all statistically significant and are unlikely to be caused by natural variability. When it comes to individual model response (Figs. S2 and S3), these patterns are also consistent across at least eight of the nine models and are not very sensitive to the model setup (emission-based or concentration-based). For $\mathrm{SO}_{4}$, the SWCRE changes are relatively small compared with the other two forcings, and few significant changes are found over low-latitude to midlatitude regions. When domain-averaged (green boxes in Fig. 2), the MMM SWCRE from $\mathrm{CO}_{2}$ forcing is $1.7 \mathrm{~W} \mathrm{~m}^{-2}$ (N. America), $2.0 \mathrm{~W} \mathrm{~m}^{-2}$ (Europe), and $1.5 \mathrm{~W} \mathrm{~m}^{-2}$ (E. China) for the indicated regions. The SWCRE of BC forcing is $7.0 \mathrm{~W} \mathrm{~m}^{-2}(\mathrm{~N}$. America), $9.0 \mathrm{~W} \mathrm{~m}^{-2}$ (Europe), and $9.4 \mathrm{~W} \mathrm{~m}^{-2}$ (E. China), which is roughly 3 to 5 times larger than that from $\mathrm{CO}_{2}$ forcing, whereas sulfate aerosols induced $1.2 \mathrm{~W} \mathrm{~m}^{-2}$ over E. China and a near-zero impact in N. America and Europe, with even the sign of change being uncertain (Figs. 3 and S4). Such SWCRE changes could be largely explained by the changes in cloud cover (Fig. 2d-f). Low-level cloud cover decreased significantly in regions where SWCRE is positive for $\mathrm{CO}_{2}$ and $\mathrm{BC}$ forcing, with a stronger decrease from the latter, indicating that the cloud response is more sensitive to $\mathrm{BC}$ forcing than to WMGHGs. The sulfate aerosols caused increased cloud cover over midlatitudes (Fig. 2f). The cloud cover in other levels shows similar patterns of change (Fig. S5). In order to better understand these cloud responses, we will explore a set of potential mechanisms driving such changes.

\subsection{Mechanism of the cloud changes}

Clouds form when air rises and cools to saturation, and they are thus closely linked to changes in RH (Fig. 4a-c). The general pattern of RH changes corresponds well with cloud cover changes (Fig. 2d-f). That is, the cloud cover decreases 
Table 1. Descriptions of the nine PDRMIP models used in this study, adapted from Tang et al. (2019).

\begin{tabular}{|c|c|c|c|c|c|}
\hline Model name & Version & Resolution & Ocean setup & Aerosol setup & References \\
\hline CanESM & 2010 & $\begin{array}{l}2.8 \times 2.8 \\
35 \text { levels }\end{array}$ & Coupled & Emission & Arora et al. (2011) \\
\hline GISS-E2 & E2-R & $\begin{array}{l}2 \times 2.5 \\
40 \text { levels }\end{array}$ & Coupled & Fixed concentration & Schmidt et al. (2014) \\
\hline HadGEM2-ES & 6.6 .3 & $\begin{array}{l}1.875 \times 1.25 \\
38 \text { levels }\end{array}$ & Coupled & Emissions & Collins et al. (2011) \\
\hline HadGEM3 & GA 4.0 & $\begin{array}{l}1.875 \times 1.25 \\
85 \text { levels }\end{array}$ & Coupled & Fixed concentration & $\begin{array}{l}\text { Bellouin et al. (2011) } \\
\text { Walters et al. (2014) }\end{array}$ \\
\hline MIROC-SPRINTARS & 5.9 .0 & $\begin{array}{l}\text { T85 } \\
40 \text { levels }\end{array}$ & Coupled & HTAP2 emissions & $\begin{array}{l}\text { Takemura et al. (2009) } \\
\text { Takemura et al. (2005) } \\
\text { Watanabe et al. (2010) }\end{array}$ \\
\hline CESM-CAM4 & 1.0 .3 & $\begin{array}{l}2.5 \times 1.9 \\
26 \text { levels }\end{array}$ & Slab & Fixed concentration & $\begin{array}{l}\text { Neale et al. (2010) } \\
\text { Gent et al. (2011) }\end{array}$ \\
\hline CESM-CAM5 & 1.1.2 & $\begin{array}{l}2.5 \times 1.9 \\
30 \text { levels }\end{array}$ & Coupled & Emissions & $\begin{array}{l}\text { Hurrell et al. (2013) } \\
\text { Kay et al. (2015) } \\
\text { Otto-Bliesner et al. (2016) }\end{array}$ \\
\hline NorESM & $1-\mathrm{M}$ & $\begin{array}{l}2.5 \times 1.9 \\
26 \text { levels }\end{array}$ & Coupled & Fixed concentration & $\begin{array}{l}\text { Bentsen et al. (2013) } \\
\text { Iversen et al. (2013) } \\
\text { Kirkevåg et al. (2013) }\end{array}$ \\
\hline IPSL-CM & $5 \mathrm{~A}$ & $\begin{array}{l}3.75 \times 1.9 \\
19 \text { levels }\end{array}$ & Coupled & Fixed concentration & Dufresne et al. (2013) \\
\hline
\end{tabular}

GA: global atmosphere. HTAP2: Hemispheric Transport Air Pollution Phase 2.

(a)

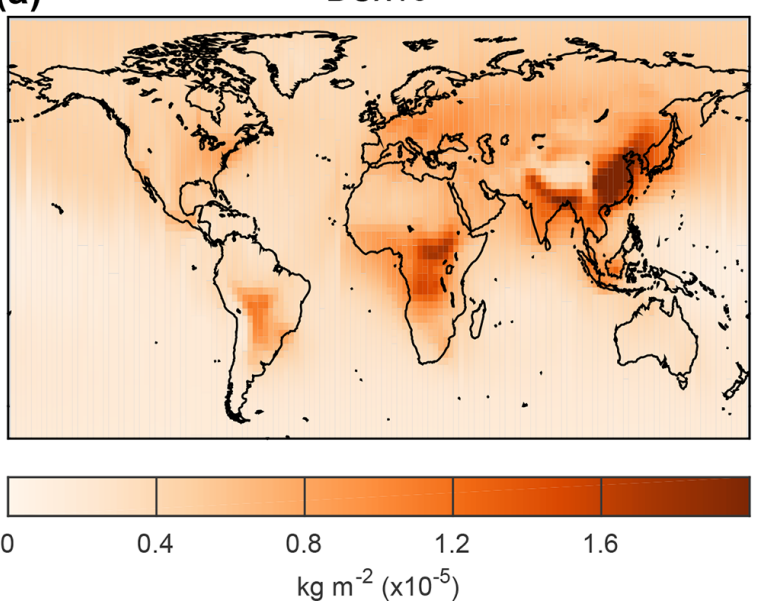

(b)
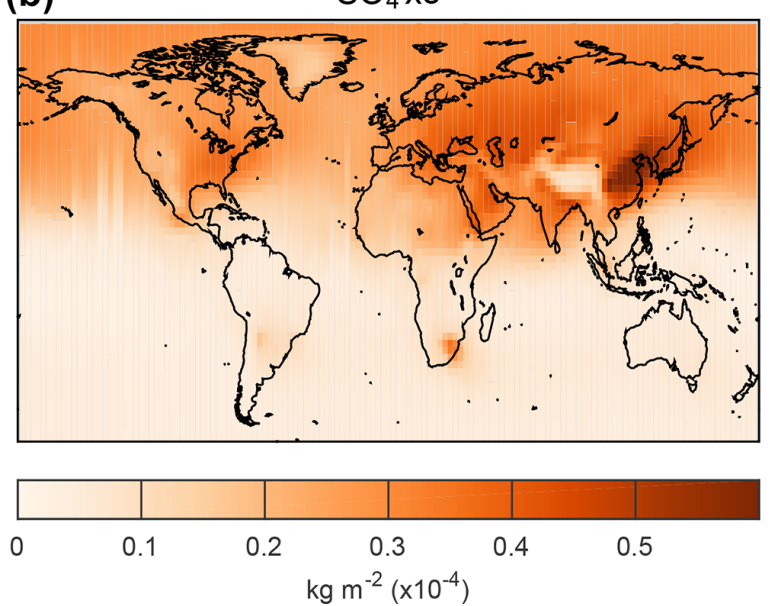

Figure 1. Aerosol loadings for the two aerosol experiments in the CanESM2 model (as an illustrative example).

in regions where the $\mathrm{RH}$ drops and vice versa for most areas. A larger $\mathrm{RH}$ reduction due to $\mathrm{BC}$ compared with $\mathrm{CO}_{2}$ also aligns with a larger cloud cover decrease under $\mathrm{BC}$ forcing, especially over N. America and Europe. This spatial pattern is not surprising as it is easier for air masses to reach saturation in conditions with higher RH. By defini- tion, RH depends on both specific humidity and saturation vapor pressure (which, in turn, depends on temperature). To probe which factor determines the RH changes, we further analyzed specific humidity changes (Fig. 4d-f). Specific humidity increases ubiquitously under both $\mathrm{CO}_{2}$ and $\mathrm{BC}$ scenarios as a result of increased evaporation in a warmer cli- 

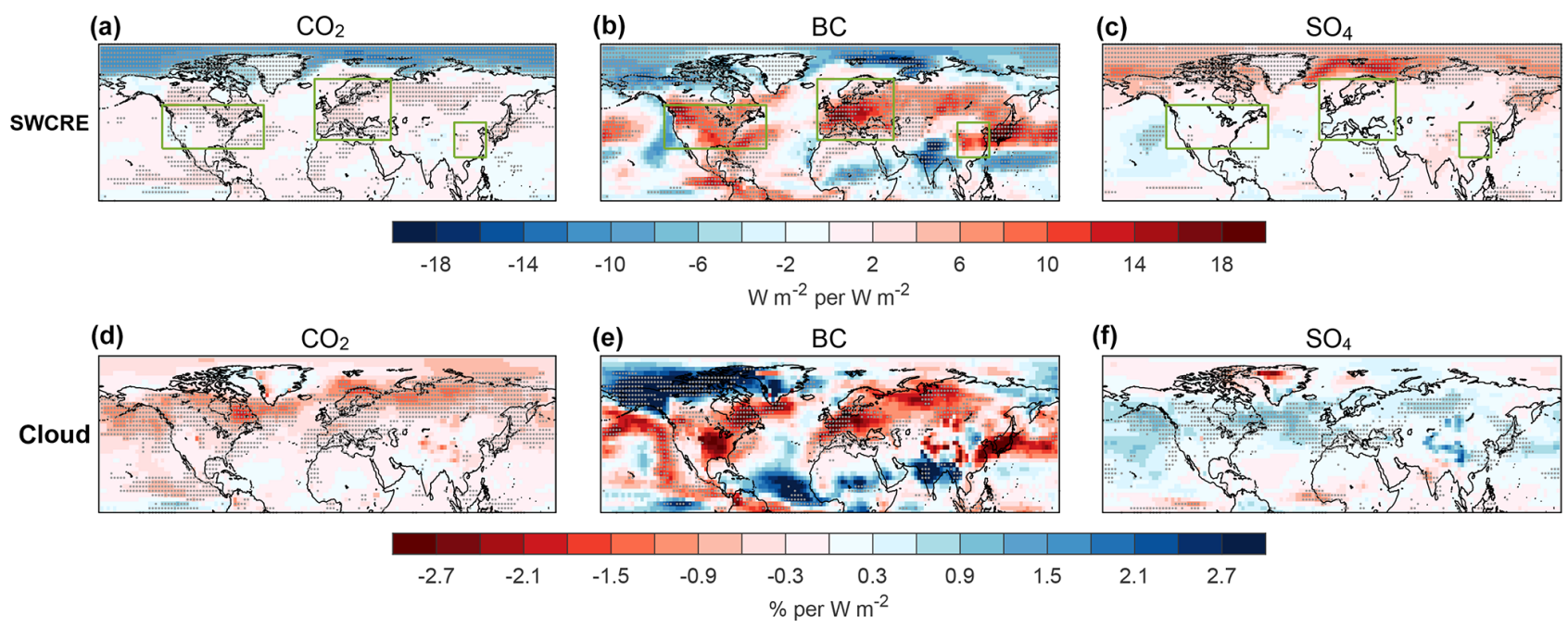

Figure 2. SWCRE changes (a-c) and cloud cover changes per unit forcing at $850 \mathrm{hPa}(\mathbf{d}-\mathbf{f})$ in JJA; results for $\mathrm{SO}_{4}$ are changes per negative forcing. Grey dots indicate that changes are significant at the 0.05 level. Positive anomalies in (a-c) indicate more radiation reaching the surface.

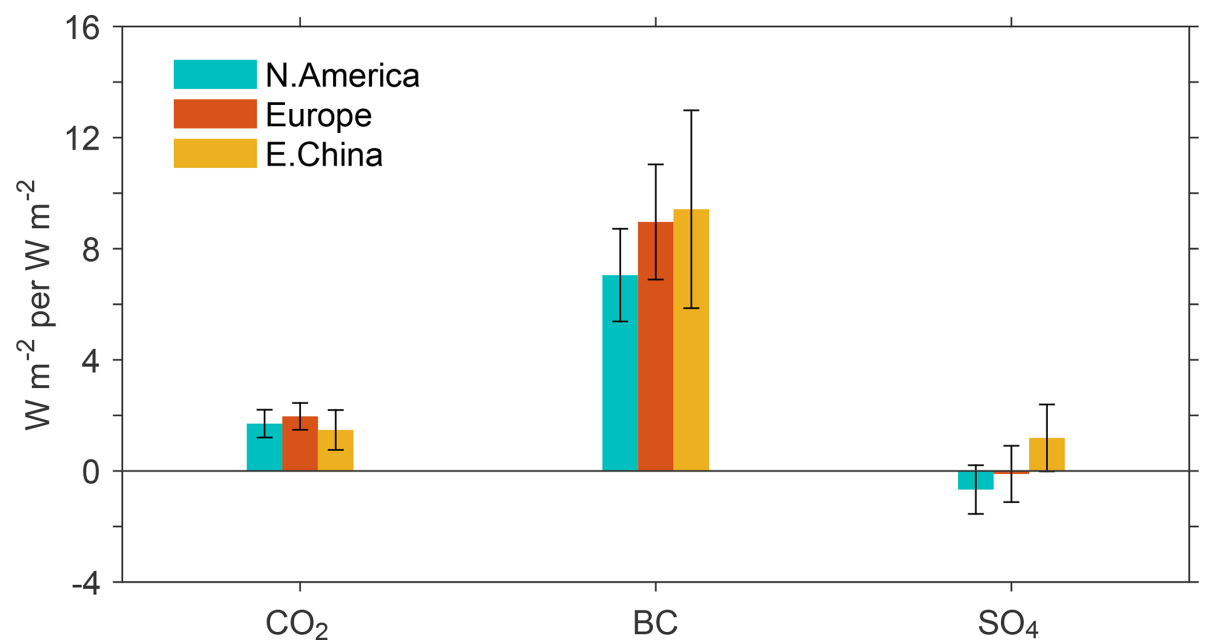

Figure 3. Domain-averaged SWCRE changes for three regions (green boxes in Fig. 2). Bars represent MMM results, and error bars indicate 1 standard error across the models.

mate. Thus, the main driver of the RH drop is the atmospheric temperature that drives a faster increase in saturation vapor pressure. Figure 5 shows the changes in vapor pressure as a function of temperature change over Europe at $850 \mathrm{hPa}$. For example, the temperature increases by $\sim 1.1 \mathrm{~K}$ under $\mathrm{CO}_{2}$ forcing, accompanied by $\sim 0.02 \mathrm{kPa}$ vapor pressure increase. Such a vapor pressure increase, however, cannot keep pace with the rise in saturation vapor pressure, which is about $0.1 \mathrm{kPa}$. Consequently, the RH decreases in Europe, and this is also the case for most other land areas. BC causes stronger temperature increases (and hence larger RH drop) in Europe and $\mathrm{N}$. America, explaining the larger cloud cover reductions compared with $\mathrm{CO}_{2}$. In the source regions of $\mathrm{BC}$, such as India and tropical Africa, the RH increases because of stronger increases in specific humidity, combined with weak or no temperature changes (Fig. S6). The response of cloud liquid water in the $\mathrm{BC}$ experiment could further support this conclusion (Fig. 4h). Liquid water decreases (increases) in regions with decreasing (increasing) cloud cover, following the pattern of RH. As cloud water content directly impacts cloud optical thickness and albedo, such a response may further impact SWCRE (i.e., enhance reflectance in regions showing increasing liquid water and enhance transmittance in regions with decreasing liquid water). However, the liquid water responses under $\mathrm{CO}_{2}$ and sulfate aerosols are much weaker and only significant in parts of Asia and tropical Africa (Fig. 4g and i). 

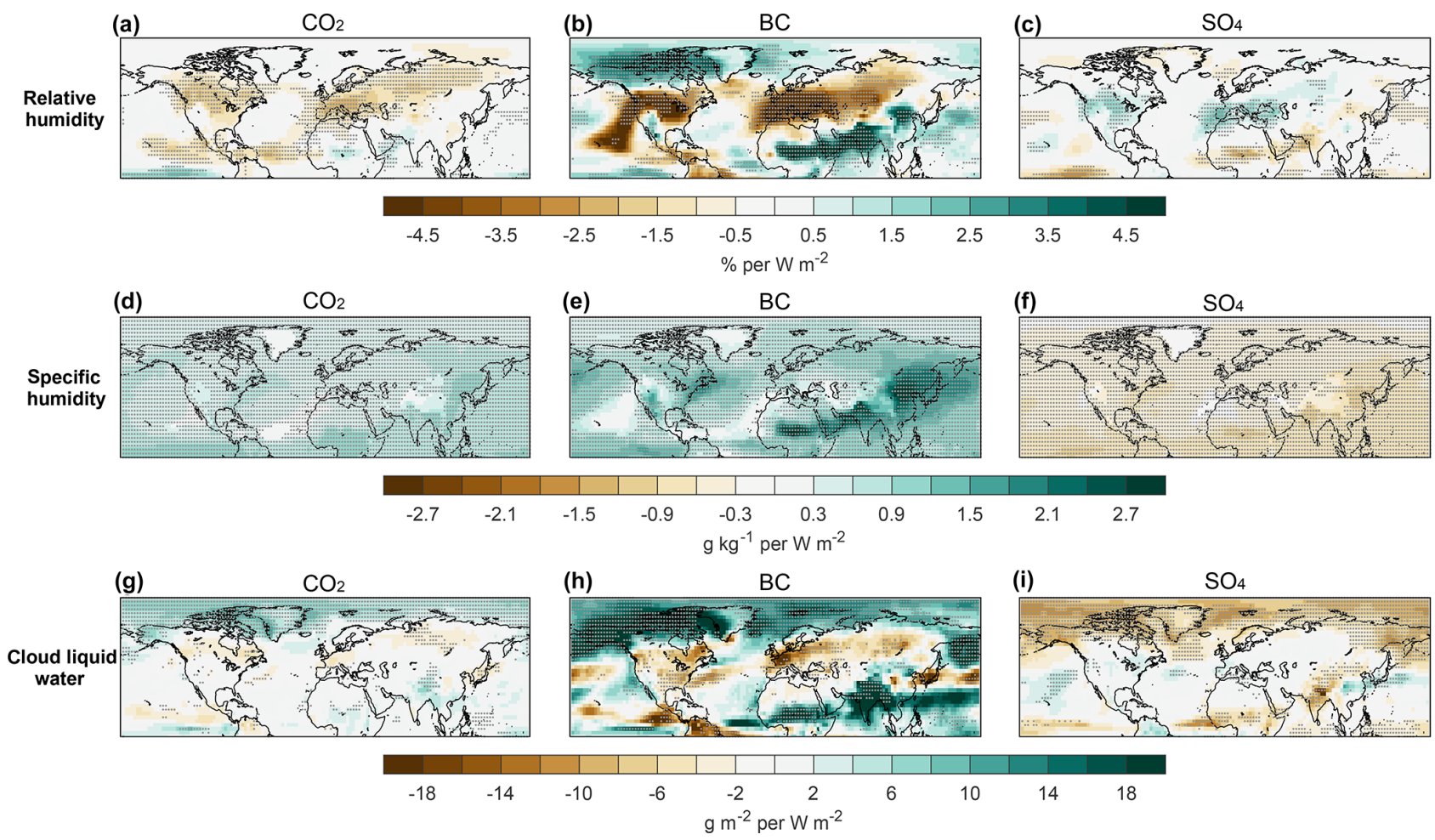

Figure 4. Same as Fig. 2, but for humidity at $850 \mathrm{hPa}$.

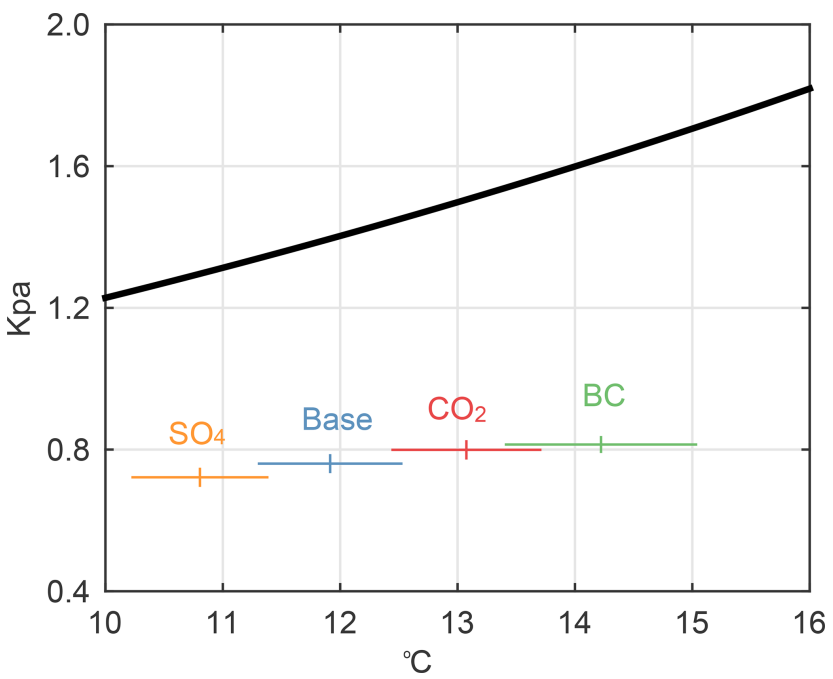

Figure 5. Domain-averaged vapor pressure changes per unit forcing as a function of temperature at $850 \mathrm{hPa}$ for Europe. Error bars indicate 1 standard error across the models. The thick black line represents saturation vapor pressure.

Changes in moisture flux, dynamics, and stability may also play a role in altering specific humidity and cloud formation (Bretherton, 2015). Here we analyze the changes in MFC, vertical velocity (omega), and lower tropospheric stability (LTS) and find significant changes under the BC experiment again (Fig. 6). It is seen that more moisture is transported to tropical Africa and India (Fig. 6b), which could explain the abovementioned increases in specific humidity in these regions despite their lack of warming. A similar response was noted by Liu et al. (2018), who suggested that more moisture could be brought into monsoon regions due to $\mathrm{BC}$ forcing. Koch and Del Genio (2010) noted that BC particles could promote cloud cover in convergent regions as they enhance deep convection and low-level convergence when drawing in moisture from ocean to land regions. This is also observed in our analyses, for example over Africa, northern India, Pakistan, and parts of northern China (Fig. 6b and e), which is consistent with the dynamic cloud response mechanism noted by Myers and Norris (2013). However, these impacts may be further compounded by cloud type, circulation, and the altitude of $\mathrm{BC}$ particles relative to the clouds (Koch and Del Genio, 2010; Samset and Myhre, 2015). The changes in moisture flux and dynamics in the $\mathrm{CO}_{2}$ experiment are relatively weaker compared with those from $\mathrm{BC}$, and most of the changes are only observed in low-latitude regions, possibly due to the shift of the Intertropical Convergence Zone (ITCZ) or monsoon circulations. The sulfate aerosols, on the other hand, generally show opposite changes to those from $\mathrm{CO}_{2}$ and $\mathrm{BC}$ (Fig. 4c and f) owing to sulfate's cooling effect. Another mechanism that has been reported to influence cloud cover is LTS, in which a stable boundary layer could trap more moisture, thereby permitting more low-level 

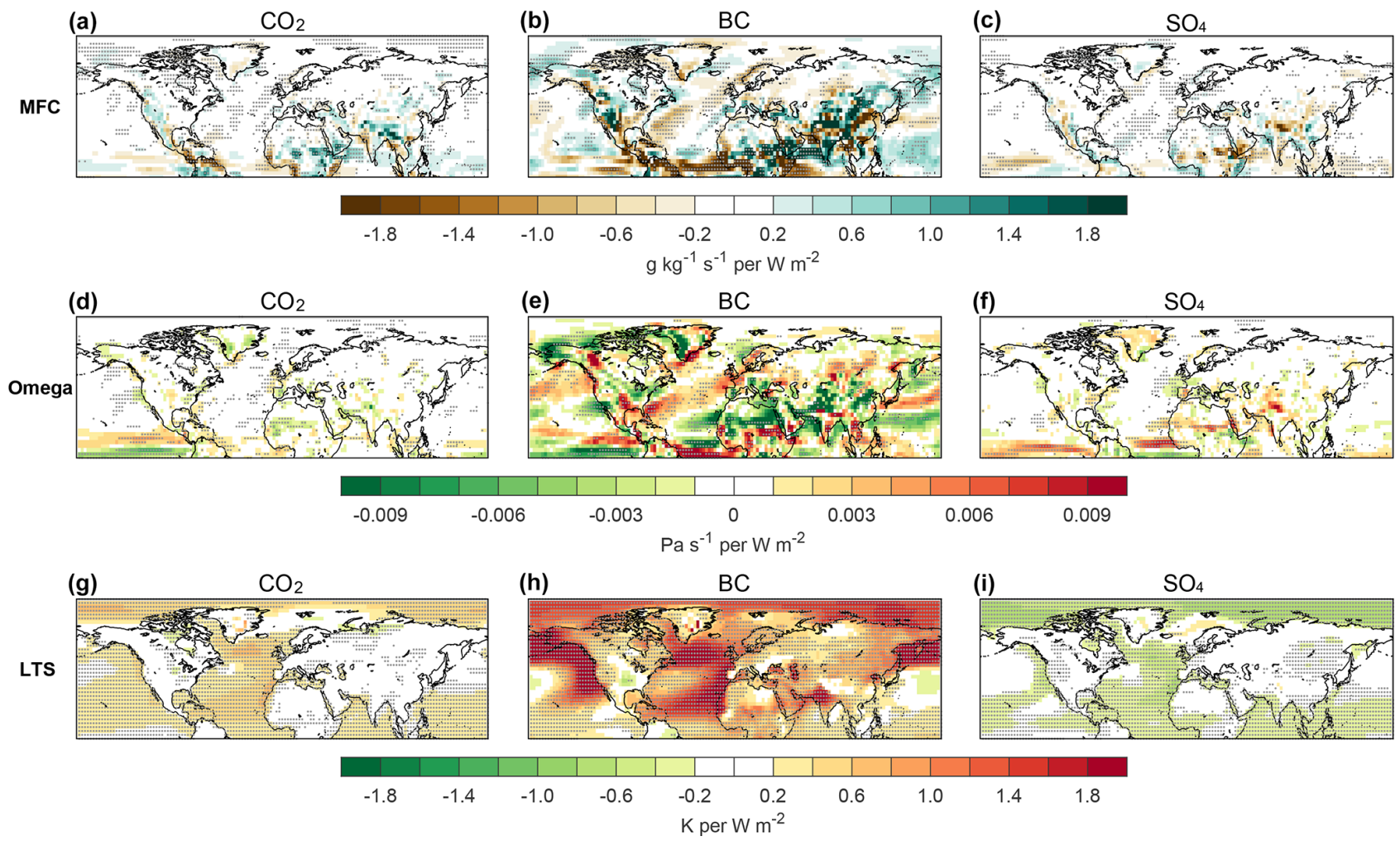

Figure 6. Same as Fig. 2, but for changes in moisture flux convergence (MFC, a-c), vertical velocity (omega, d-f), and lower tropospheric stability (LTS, g-i) per unit forcing. For vertical velocity (omega), positive anomalies indicate the air is less convective. LTS is calculated as the difference of potential temperature between $700 \mathrm{hPa}$ and the surface. Positive LTS anomalies in (g-i) indicate stronger inversion or a weaker lapse rate.

(a)

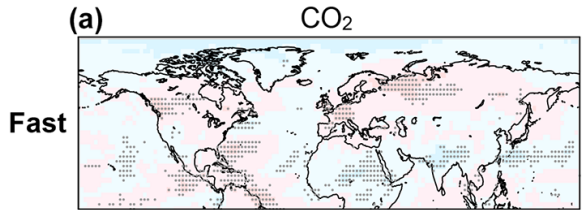

(d)

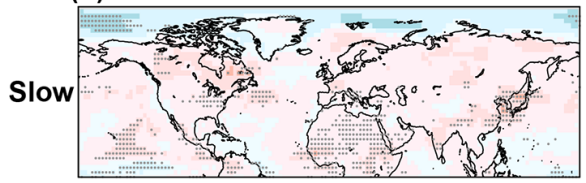

(b)

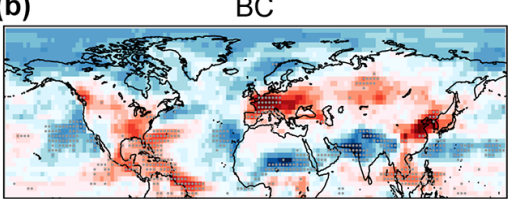

(e)

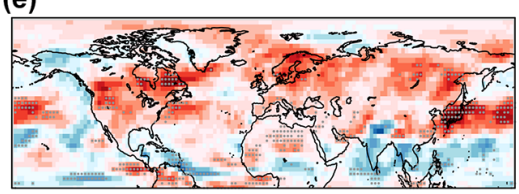

(c)

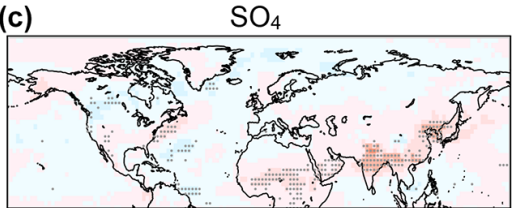

(f)

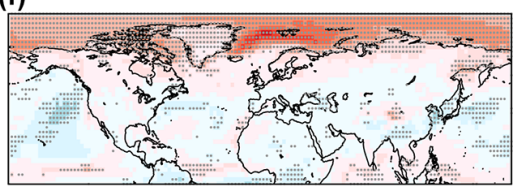

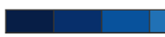

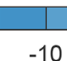

$\mathrm{W} \mathrm{m}^{-2}$ per $\mathrm{W} \mathrm{m}^{-2}$

Figure 7. Same as Fig. 2d-f, but for fast (a-c) and slow responses (d-f) of SWCRE changes per unit forcing.

clouds (Wood and Bretherton, 2006; Bretherton, 2015). In order to investigate this mechanism, we further analyzed LTS, defined as the difference of potential temperature between $700 \mathrm{hPa}$ and the surface (Fig. 6g-i), in which positive anomalies indicate a stronger inversion or a weaker lapse rate. The LTS response is again strongest in response to $\mathrm{BC}$ forcing (Fig. 6h), with a widespread increase in stability. A previously reported positive correlation between LTS and low- level cloud cover is, nonetheless, only observed in BC source regions (tropical Africa and India) and parts of the central US (Fig. 6h). The LTS responses over land are much weaker in response to $\mathrm{CO}_{2}$ and $\mathrm{SO}_{4}$ forcing, with some responses in Africa and India in response to sulfate aerosols (weaker inversion and less cloud). Some other factors have also been suggested to play a role in modifying low-level clouds, such as the diurnal cycle (Caldwell and Bretherton, 2009) and ra- 


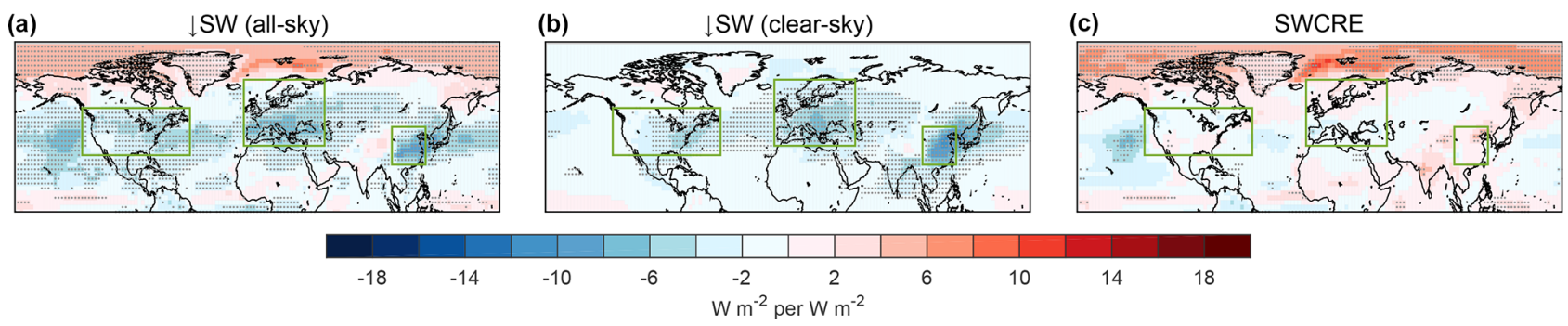

Figure 8. Changes in SW flux per unit negative forcing under all-sky (a) and clear-sky (b) conditions as well as their difference (c) for the $\mathrm{SO}_{4}$ experiment.

diative effects of cirrus clouds (Christensen et al., 2013). Due to the limited model output, however, we acknowledge that it is impossible to examine these factors in the current study and it is beyond the scope of our study to probe all possible factors driving the cloud changes. In summary, the above analyses illustrate that the cloud cover changes we see can be primarily explained by RH changes and, to a lesser extent, changes in liquid water content, circulation, dynamics, and stability.

\subsection{Fast and slow responses}

The above responses shown are total responses, which could be further split into fast responses (also called rapid adjustments) and slow responses (Andrews et al., 2010; Boucher et al., 2013). The fast responses generally occur within weeks to a few months, with the global mean temperature unchanged, and also with the expectation of a small change over land, which could be obtained by fsst simulations. The slow response mainly depends on global mean temperature change, which could be estimated by the difference between coupled simulations and fsst simulations, assuming the total response is a linear combination of fast response and slow responses (Samset et al., 2016; Stjern et al., 2017). For the $\mathrm{CO}_{2}$ experiment, fast responses dominated in E. US and Europe, while both fast and slow responses influence Asia (Fig. 7). When it comes to BC, both fast and slow responses are important in these regions, and in some regions the fast and slow response even show opposite changes (e.g., N. Europe). This is consistent with the findings of Stjern et al. (2017) that the response of cloud amount under BC forcing typically consists of opposite rapid adjustments. Regarding sulfate aerosols, the SWCRE changes are much weaker, with both fast and slow responses influencing Asia and Africa. As discussed in Sect. 3.2, the slow responses in Asia are likely to be associated with circulation changes, as significant changes in MFC, omega, and stability are observed in tropical regions and monsoon regions across all three experiments (Fig. 6). These circulation changes could be, but are not limited to, shifts in the monsoons or ITCZ and tropical expansion, and both greenhouse gases and aerosols have been reported to impact these circulations (Menon et al., 2002; Wang, 2007;
Meehl et al., 2008; Seidel et al., 2008; Allen et al., 2012; Turner and Annamalai, 2012).

\subsection{SWCRE response to sulfate aerosol}

Another interesting phenomenon worth noting is the relatively small change in SWCRE induced by sulfate aerosols compared with $\mathrm{CO}_{2}$ and $\mathrm{BC}$. SWCRE at the surface is obtained as the difference of SW fluxes between all-sky and clear-sky conditions (Fig. 8). However, both clouds and aerosol particles scatter solar radiation, so at least part of the radiation scattered by clouds under all-sky conditions will also be scattered by aerosols under clear-sky conditions (no clouds). This means the SW radiation change at the surface due to scattering may not be as sensitive to cloud fraction changes, which leads to reduced changes in their difference (SWCRE), at least in the source regions (Fig. 8). The SWCRE under sulfate aerosols will not be further discussed due to its small radiative impact at the surface.

\subsection{Impact on radiation and $T_{\max }$}

From the energy perspective, the net incoming radiation $\left(R_{\text {in }}\right)$ at the surface is the combination of downward SW radiation and downward longwave (LW) radiation minus the reflected $\mathrm{SW}$ radiation $\left(R_{\text {in }}=\downarrow \mathrm{SW}-\uparrow \mathrm{SW}+\downarrow \mathrm{LW}\right) . R_{\text {in }}$ represents the total energy available to maintain the surface temperature and to sustain the turbulent fluxes (Philipona et al., 2009). The surface responds to the imposed $R_{\text {in }}$ by redistributing the altered energy content among the outgoing LW radiation and nonradiative fluxes (ground heat flux and turbulent flux) (Wild et al., 2004). Because SW radiation is in effect only during daytime, while LW radiation works both day and night, $R_{\text {in }}$ is directly related to $T_{\max }$. In a perturbed climate, both SW and LW radiation will change, thereby changing $R_{\text {in }}$ and $T_{\max }$. The net SW radiation change is further linearly decomposed into SW changes under clear-sky conditions and SWCRE changes. The changes in $R_{\text {in }}$ and its individual components, as well as $T_{\max }$, are shown in Fig. 9. For the $\mathrm{CO}_{2} \times 2$ experiment, the SW under clear-sky conditions shows slight decreases over most land surfaces, mainly due to the absorption of SW radiation by enhanced water vapor, except for some high-latitude regions where the albedo 

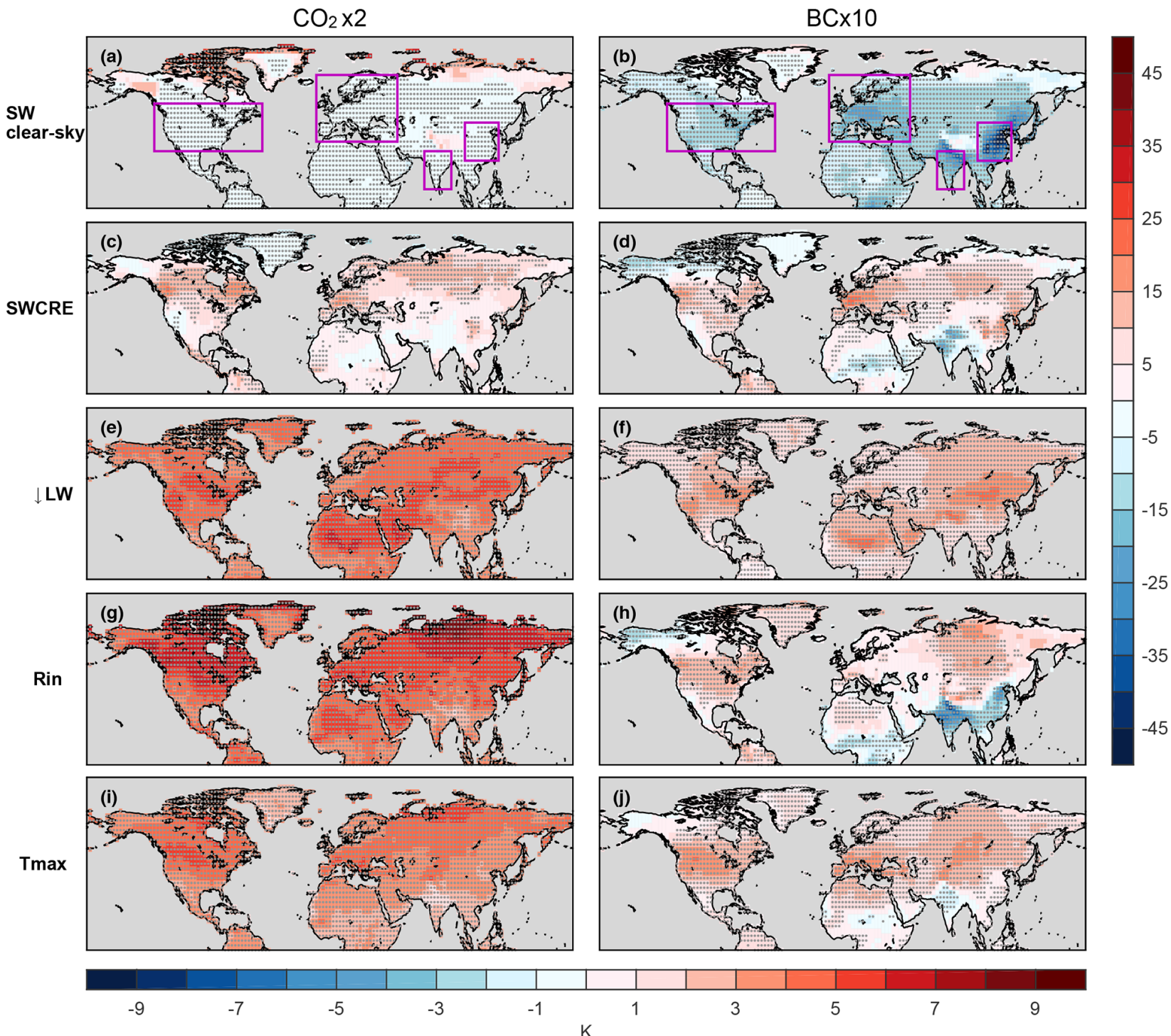

Figure 9. Changes in $R_{\text {in }}$ and its components $(\mathbf{a}-\mathbf{h})$ as well as changes in $T_{\max }(\mathbf{i}-\mathbf{j})$ for the $\mathrm{CO}_{2} \times 2(\mathbf{a}, \mathbf{c}, \mathbf{e}, \mathbf{g}, \mathbf{i})$ and $\mathrm{BC} \times 10(\mathbf{b}, \mathbf{d}, \mathbf{f}, \mathbf{h}, \mathbf{j})$ experiments (original output, no normalization applied).

effect is important (Fig. 9a). Combined with the changes in SWCRE and $\downarrow \mathrm{LW}$ radiation, $R_{\text {in }}$ shows significant increases over all land surfaces and thus increasing $T_{\max }$ (Fig. $9 \mathrm{~g}$ and i). The $\mathrm{BC} \times 10$ experiment shows similar responses, with significantly negative SW radiation under clear-sky conditions due to SW absorption by BC particles (Fig. 9b) and enhanced $\downarrow$ LW radiation resulting from atmospheric heating (Fig. 9f). The resulting $R_{\text {in }}$ changes largely explained $T_{\max }$ changes on the first order, with cooling observed in source regions (India and tropical Africa) and warming elsewhere (Fig. 9h and j). Nonetheless, some exceptions occurred (i.e., E. China), with decreased $R_{\text {in }}$ but increased $T_{\max }$, possibly due to the atmospheric heat transport (Menon et al., 2002) and reduced turbulent fluxes (Wild et al., 2004).
In order to further determine the contributions to $T_{\max }$ changes from each individual radiative component, a multilinear regression model is applied by regressing $T_{\max }$ changes to $\mathrm{SW}_{\text {clear-sky }}$, SWCRE and $\downarrow \mathrm{LW}$ radiation changes with zero intercept, obtaining the following models.

$$
\begin{aligned}
\mathrm{CO}_{2} \times 2: & \\
T_{\text {max }}= & 0.08 \times \mathrm{SW}_{\text {clear-sky }}+0.15 \times \mathrm{SWCRE}+0.14 \\
& \times \downarrow \mathrm{LW}\left(R^{2}=0.73, p<0.001\right) \\
\mathrm{BC} \times 10: & \\
T_{\max }= & 0.05 \times \mathrm{SW}_{\text {clear-sky }}+0.13 \times \mathrm{SWCRE}+0.15 \\
& \times \downarrow \mathrm{LW}\left(R^{2}=0.80, p<0.001\right)
\end{aligned}
$$

All values in the linear models are MMM changes in each experiment. The models could explain $73 \%$ and $80 \%$ of the 

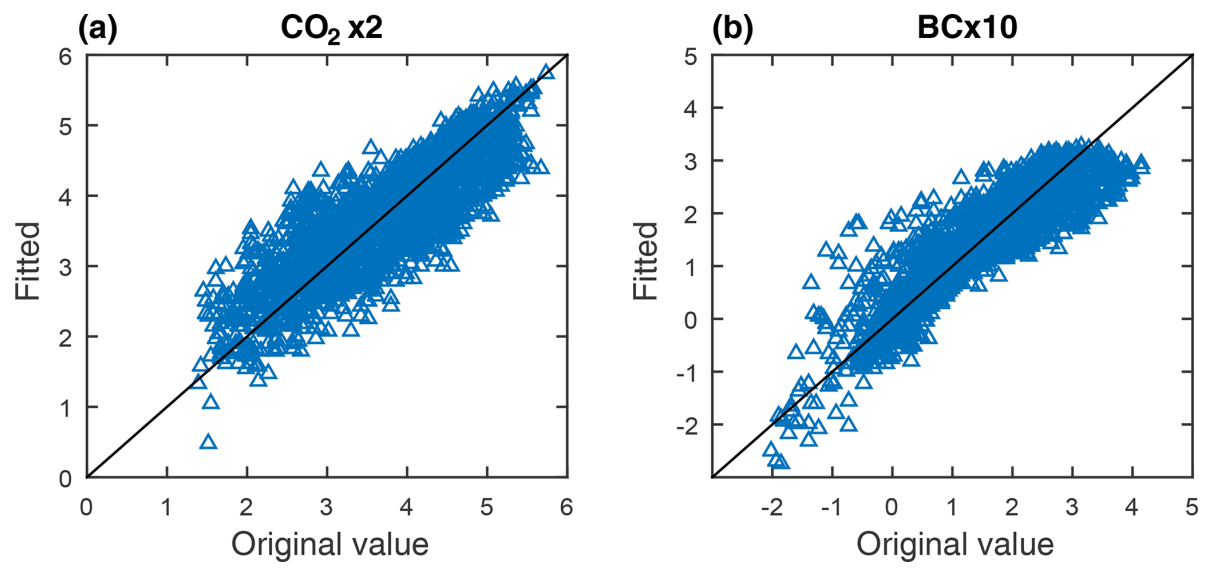

Figure 10. Comparison of fitted $T_{\max }$ from the linear models vs. original $T_{\max }$ values. Blue triangles are values for all grid boxes over the $\mathrm{NH}$, and the black solid line represents the one-to-one line.

Table 2. Domain-averaged $T_{\max }$ changes from each radiative component estimated from the linear models (K).

\begin{tabular}{lrrrr}
\hline & \multicolumn{4}{c}{$\mathrm{CO}_{2} \times 2$} \\
\cline { 2 - 5 } Region & $\mathrm{SW}_{\text {clear-sky }}$ & $\mathrm{SWCRE}$ & $\downarrow \mathrm{LW}$ & Total \\
\hline N. America & $-0.27 \pm 0.01$ & $0.95 \pm 0.02$ & $3.24 \pm 0.03$ & $3.92 \pm 0.06$ \\
Europe & $-0.24 \pm 0.01$ & $1.14 \pm 0.03$ & $2.79 \pm 0.02$ & $3.69 \pm 0.06$ \\
E. China & $-0.23 \pm 0.01$ & $0.71 \pm 0.02$ & $2.82 \pm 0.02$ & $3.30 \pm 0.05$ \\
India & $-0.29 \pm 0.01$ & $0.26 \pm 0.01$ & $2.59 \pm 0.02$ & $2.56 \pm 0.04$ \\
\hline & \multicolumn{5}{c}{$\mathrm{BC} \times 10$} \\
Region & $\mathrm{SW}$ & \multicolumn{5}{c}{$\mathrm{SWCRE}$} & \\
\hline N. America & $-0.56 \pm 0.03$ & $1.00 \pm 0.02$ & $1.94 \pm 0.04$ & $2.38 \pm 0.10$ \\
Europe & $-0.73 \pm 0.04$ & $1.15 \pm 0.03$ & $1.32 \pm 0.03$ & $1.74 \pm 0.10$ \\
E. China & $-1.40 \pm 0.08$ & $0.98 \pm 0.02$ & $1.92 \pm 0.04$ & $1.50 \pm 0.15$ \\
India & $-0.89 \pm 0.05$ & $-1.05 \pm 0.02$ & $1.10 \pm 0.02$ & $-0.84 \pm 0.05$ \\
\hline
\end{tabular}

Note: the uncertainty range was estimated from the $95 \%$ confidence interval of each coefficient.

$T_{\max }$ change in the $\mathrm{CO}_{2} \times 2$ and $\mathrm{BC} \times 10$ experiment, respectively. The coefficients represent the $T_{\max }$ change under unit radiative flux change, in which the $T_{\max }$ increases by $0.15 \mathrm{~K}(0.13 \mathrm{~K})$ per unit increase in local SWCRE under the $\mathrm{CO}_{2}$ (BC) experiment. Furthermore, the coefficients demonstrate that $T_{\max }$ changes are more sensitive to unit SWCRE and $\downarrow$ LW changes than to unit $\mathrm{SW}_{\text {clear-sky. A comparison of }}$ the original $T_{\max }$ values and the fitted values from the linear models is shown in Fig. 10. The linear models predict the $T_{\max }$ changes fairly well, with the values scattering along the one-to-one line. The contributions from each radiative component to $T_{\max }$ changes were estimated with the linear models and the domain-averaged changes for N. America, Europe, E. China, and India (purple boxes in Fig. 9a) are listed in Table 2. Physically, $T_{\max }$ increases in these regions are mainly due to the increased flux from SWCRE and $\downarrow$ LW, partially offset by the reduced flux from $\mathrm{SW}_{\text {clear-sky }}$ (Table 2 and Fig. 9). Taking N. America under the $\mathrm{CO}_{2} \times 2$ experiment as an example, the warming in $T_{\max }$ from SWCRE and $\downarrow \mathrm{LW}$ is 0.95 and $3.24 \mathrm{~K}$, respectively, in which SWCRE contributed roughly $23 \%$ to the total warming and the remaining $77 \%$ is from the $\downarrow$ LW radiation change. Such warming is offset by the $0.27 \mathrm{~K}$ cooling from SW changes under clear-sky conditions, leading to a net increase of $3.92 \mathrm{~K}$ in $T_{\max }$. The contributions of SWCRE to $T_{\max }$ increases are $29 \%$ (Europe), $20 \%$ (E. China), and $9 \%$ (India) for the indicated regions under the $\mathrm{CO}_{2} \times 2$ experiment. For the $\mathrm{BC} \times 10$ experiment, the contributions from SWCRE are larger than those in the $\mathrm{CO}_{2}$ experiment, i.e., $34 \%$ (N. America), $47 \%$ (Europe), and $34 \%$ (E. China). The response over India under the BC experiment is opposite, in which both SW components cause cooling in $T_{\max }$ due to reduced fluxes and such cooling is slightly offset by the warming from increased $\downarrow \mathrm{LW}$ radiation. In this case, the negative SWCRE change contributed $54 \%$ to the reduction in $T_{\max }$. It is noted that the radiation change might not explain all $T_{\max }$ changes, as other factors 
(a)

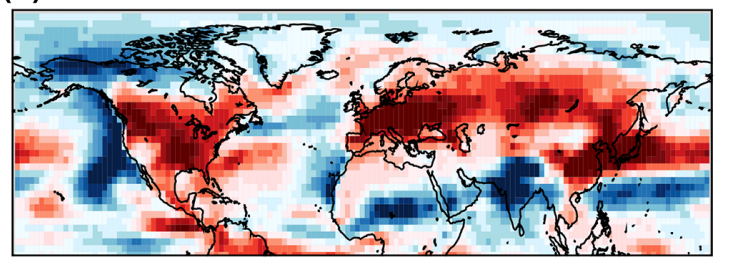

(b)

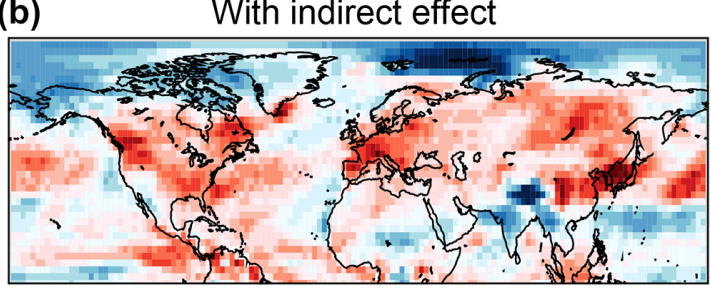

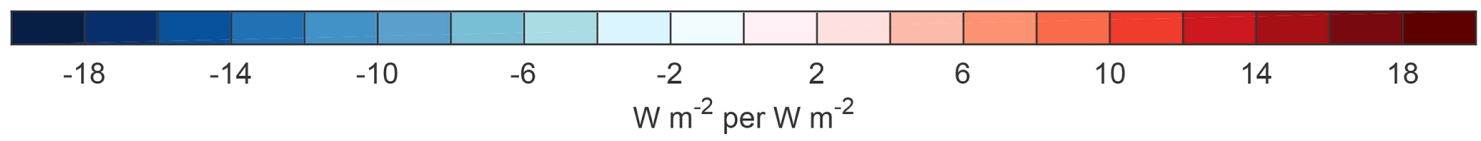

Figure 11. SWCRE changes in the BC experiment (a) for models without aerosol indirect effects and (b) for models with indirect effects.

may come into play. For instance, the temperature response would be different when the surface becomes drier under a warmer climate. This is because more net radiation is realized as sensible heat instead of latent heat under drier conditions, which has been suggested to play an important role in recent European heat waves (Seneviratne et al., 2006; Fischer et al., 2007).

\section{Discussion and summary}

Our study shows that cloud cover in the summer is reduced in a warming climate over most midlatitude land regions. The reduction of clouds, at the same time, may also reduce the warming effect by reducing downwelling LW radiation (LWCRE; Fig. S7). Specifically, the LWCRE changes per unit $\mathrm{CO}_{2}$ forcing, in $\mathrm{MMM}$, are $-1.1 \mathrm{~W} \mathrm{~m}^{-2}$ (N. America), $-0.8 \mathrm{~W} \mathrm{~m}^{-2}$ (Europe), and $-1.0 \mathrm{~W} \mathrm{~m}^{-2}$ (E. China), resulting in net CRE (SWCRE + LWCRE) changes of $0.6 \mathrm{~W} \mathrm{~m}^{-2}$ (N. America), $1.2 \mathrm{~W} \mathrm{~m}^{-2}$ (Europe), and $0.5 \mathrm{~W} \mathrm{~m}^{-2}$ (E. China) at the surface. The LWCRE changes per unit BC forcing are $-1.7 \mathrm{Wm}^{-2}\left(\mathrm{~N}\right.$. America), $-2.1 \mathrm{Wm}^{-2}$ (Europe), and $-1.5 \mathrm{Wm}^{-2}$ (E. China), leading to net CRE changes of $5.3 \mathrm{~W} \mathrm{~m}^{-2}$ (N. America), $6.9 \mathrm{~W} \mathrm{~m}^{-2}$ (Europe), and $7.9 \mathrm{~W} \mathrm{~m}^{-2}$ (E. China). The net CRE changes are positive under both forcings and work as a positive feedback in these areas. As SWCRE is only active during daytime, the CRE changes have an even more pronounced amplifying effect on summer extreme temperature in these populated regions.

Recent European heat-wave events have been linked to the shift of mean temperature (Schär et al., 2004; Barriopedro et al., 2011). Thus, the enhanced increase in summer mean $T_{\max }$ may significantly increase the number of hot days and the probability of heat-wave events. Our model simulations show that both N. America and Europe show faster increases in $T_{\max }$ than in $T_{\min }$ (daily minimum temperature) under both $\mathrm{CO}_{2}$ and $\mathrm{BC}$ experiments (figure not shown), indicating an increase in diurnal temperature range, which has also been reported by Wang and Dillon (2014). These changes can have substantial socioeconomic impacts (De Bono et al., 2004; Ciais et al., 2005), influencing human health (Robine et al., 2008), labor productivity (Kjellstrom et al., 2018), and disease transmission (Paaijmans et al., 2010), as well as environmental and other ecological functions (Vasseur David et al., 2014; Wang and Dillon, 2014).

Some limitations also exist in the current study. Firstly, aerosol-cloud interactions cannot be realistically represented, as more than half of the PDRMIP simulations were run with fixed concentrations, whereby changes in cloud lifetime cannot affect aerosols. For the BC simulations, three models include aerosol indirect effects (MIROC, NorESM, and IPSL), while the remaining ones have only aerosolradiation interactions included (instantaneous and rapid adjustments). The responses of SWCRE for the two categories are shown in Fig. 11. For the regions of interest in the current study, the positive SWCRE over N. America, Europe, and E. China and negative SWCRE over India are still observed in the models including indirect effects but with reduced magnitude. Thus, our main conclusions hold in both sets of models, since the responses do not qualitatively vary between those with indirect effects and models without those effects. Such effects are not likely to be a large source of uncertainty but merit future study. Secondly, the aerosol perturbations are idealized time-invariant $10 \times$ and $5 \times$ presentday aerosol concentrations. Such simulations provide valuable physical insights into the effects of different forcings on a variety of aspects of the climate system. Aerosol concentrations, however, changed inhomogeneously during the historical period and in recent decades, both spatially and temporally. For example, aerosol concentrations have been decreasing in Europe and N. America since the 1980s and have been increasing in Asia since the 1950s (Smith et al., 2011). Future simulations may use aerosol forcing with realistic spatiotemporal changes.

In conclusion, our study shows that both $\mathrm{CO}_{2}$ and $\mathrm{BC}$ could cause positive SWCRE changes over most regions in the $\mathrm{NH}$, with a stronger response caused by $\mathrm{BC}$, except over some key source regions of BC aerosols (e.g., India, tropical Africa) that show opposite changes. The SWCRE changes under sulfate aerosol forcing are, however, relatively small compared with the other two forcers. The SWCRE 
changes are mainly a consequence of RH changes and, to a lesser extent, liquid water, circulation, dynamics, and stability changes. The SWCRE changes may have contributed $10-50 \%$ of summer mean $T_{\max }$ increases, depending on the forcing agent and region, and contributed substantially to $T_{\max }$ decreases in the source regions of India and Africa, which has important implications for extreme climatic events and socioeconomic activities.

Code and data availability. The PDRMIP model output used in this study is available to the public through the Norwegian FEIDE data storage facility. For more information, please see http://cicero. uio.no/en/PDRMIP (last access: 13 July 2020). This study is performed by using MATLAB R 2019a. The MATLAB code is available upon reasonable request.

Supplement. The supplement related to this article is available online at: https://doi.org/10.5194/acp-20-8251-2020-supplement.

Author contributions. TT and DS designed this study. TT performed data analysis and wrote the initial paper. All authors contributed to scientific discussion, results framing, and paper polishing.

Competing interests. The authors declare that they have no conflict of interest.

Acknowledgements. We thank the two reviewers for their helpful and constructive comments. We acknowledge the NASA High-End Computing Program through the NASA Center for Climate Simulation at Goddard Space Flight Center for computational resources to run the GISS-E2R model and support from NASA GISS. Computing resources for CESM1-CAM5 (ark:/85065/d7wd3xhc) simulations were provided by the Climate Simulation Laboratory at the NCAR Computational and Information System Laboratory, sponsored by the National Science Foundation and other agencies.

Financial support. PDRMIP is partly funded through the Norwegian Research Council project NAPEX (project number 229778). Apostolos Voulgarakis is supported by NERC under grant NE/K500872/1.

The research has been supported by the project of Easm-3 from NSF of the United States (grant number 14-19398).

Review statement. This paper was edited by Pedro JimenezGuerrero and reviewed by two anonymous referees.

\section{References}

Allen, R. J., Sherwood, S. C., Norris, J. R., and Zender, C. S.: Recent Northern Hemisphere tropical expansion primarily driven by black carbon and tropospheric ozone, Nature, 485, 350-354, https://doi.org/10.1038/nature11097, 2012.

Andrews, T., Forster, P. M., Boucher, O., Bellouin, N., and Jones, A.: Precipitation, radiative forcing and global temperature change, Geophys. Res. Lett., 37, L14701, https://doi.org/10.1029/2010gl043991, 2010.

Andrews, T., Gregory, J. M., Webb, M. J., and Taylor, K. E.: Forcing, feedbacks and climate sensitivity in CMIP5 coupled atmosphere-ocean climate models, Geophys. Res. Lett., 39, L09712, https://doi.org/10.1029/2012gl051607, 2012.

Andrews, T., Gregory, J. M., and Webb, M. J.: The dependence of radiative forcing and feedback on evolving patterns of surface temperature change in climate models, J. Climate, 28, 16301648, https://doi.org/10.1175/Jcli-D-14-00545.1, 2015.

Andrews, T., Gregory, J. M., Paynter, D., Silvers, L. G., Zhou, C., Mauritsen, T., Webb, M. J., Armour, K. C., Forster, P. M., and Titchner, H.: Accounting for changing temperature patterns increases historical estimates of climate sensitivity, Geophys. Res. Lett., 45, 8490-8499, https://doi.org/10.1029/2018gl078887, 2018.

Arora, V. K., Scinocca, J. F., Boer, G. J., Christian, J. R., Denman, K. L., Flato, G. M., Kharin, V. V., Lee, W. G., and Merryfield, W. J.: Carbon emission limits required to satisfy future representative concentration pathways of greenhouse gases, Geophys. Res. Lett., 38, L05805, https://doi.org/10.1029/2010GL046270, 2011.

Banacos, P. C. and Schultz, D. M.: The use of moisture flux convergence in forecasting convective initiation: Historical and operational perspectives, Weather Forecast., 20, 351-366, https://doi.org/10.1175/WAF858.1, 2005.

Barriopedro, D., Fischer, E. M., Luterbacher, J., Trigo, R. M., and García-Herrera, R.: The hot summer of 2010: Redrawing the temperature record map of Europe, Science, 332, 220, https://doi.org/10.1126/science.1201224, 2011.

Bellouin, N., Rae, J., Jones, A., Johnson, C., Haywood, J., and Boucher, O.: Aerosol forcing in the Climate Model Intercomparison Project (CMIP5) simulations by HadGEM2-ES and the role of ammonium nitrate, J. Geophys. Res.-Atmos., 116, https://doi.org/10.1029/2011JD016074, 2011.

Bentsen, M., Bethke, I., Debernard, J. B., Iversen, T., Kirkevåg, A., Seland, Ø., Drange, H., Roelandt, C., Seierstad, I. A., Hoose, C., and Kristjánsson, J. E.: The Norwegian Earth System Model, NorESM1-M - Part 1: Description and basic evaluation of the physical climate, Geosci. Model Dev., 6, 687-720, https://doi.org/10.5194/gmd-6-687-2013, 2013.

Boucher, O., Randall, D., Artaxo, P., Bretherton, C., Feingold, G., Forster, P., Kerminen, V.-M., Kondo, Y., Liao, H., and Lohmann, U.: Clouds and aerosols, in: Climate change 2013: The physical science basis, Contribution of working group i to the fifth assessment report of the Intergovernmental Panel on Climate Change, Cambridge University Press, Cambridge, UK, New York, USA, 571-657, 2013.

Bretherton, C. S.: Insights into low-latitude cloud feedbacks from high-resolution models, Philos. T. Roy. Soc. A, 373, 20140415, https://doi.org/10.1098/rsta.2014.0415, 2015. 
Caldwell, P. and Bretherton, C. S.: Large eddy simulation of the diurnal cycle in Southeast Pacific stratocumulus, J. Atmos. Sci., 66, 432-449, https://doi.org/10.1175/2008JAS2785.1, 2009.

Cheruy, F., Dufresne, J. L., Hourdin, F., and Ducharne, A.: Role of clouds and land-atmosphere coupling in midlatitude continental summer warm biases and climate change amplification in CMIP5 simulations, Geophys. Res. Lett., 41, 6493-6500, https://doi.org/10.1002/2014GL061145, 2014.

Chiriaco, M., Bastin, S., Yiou, P., Haeffelin, M., Dupont, J.-C., and Stéfanon, M.: European heatwave in july 2006: Observations and modeling showing how local processes amplify conducive large-scale conditions, Geophys. Res. Lett., 41, 56445652, https://doi.org/10.1002/2014GL060205, 2014.

Christensen, M. W., Carrió, G. G., Stephens, G. L., and Cotton, W. R.: Radiative impacts of free-tropospheric clouds on the properties of marine stratocumulus, J. Atmos. Sci., 70, 31023118, https://doi.org/10.1175/JAS-D-12-0287.1, 2013.

Chuang, C. C., Penner, J. E., Prospero, J. M., Grant, K. E., Rau, G. H., and Kawamoto, K.: Cloud susceptibility and the first aerosol indirect forcing: Sensitivity to black carbon and aerosol concentrations, J. Geophys. Res.-Atmos., 107, AAC 1011-AAC 10-23, https://doi.org/10.1029/2000JD000215, 2002.

Chung, E.-S. and Soden, B. J.: Hemispheric climate shifts driven by anthropogenic aerosol-cloud interactions, Nat. Geosci., 10, 566, https://doi.org/10.1038/ngeo2988, 2017.

Ciais, P., Reichstein, M., Viovy, N., Granier, A., Ogée, J., Allard, V., Aubinet, M., Buchmann, N., Bernhofer, C., Carrara, A., Chevallier, F., De Noblet, N., Friend, A. D., Friedlingstein, P., Grünwald, T., Heinesch, B., Keronen, P., Knohl, A., Krinner, G., Loustau, D., Manca, G., Matteucci, G., Miglietta, F., Ourcival, J. M., Papale, D., Pilegaard, K., Rambal, S., Seufert, G., Soussana, J. F., Sanz, M. J., Schulze, E. D., Vesala, T., and Valentini, R.: Europe-wide reduction in primary productivity caused by the heat and drought in 2003, Nature, 437, 529-533, https://doi.org/10.1038/nature03972, 2005.

Clement, A. C., Burgman, R., and Norris, J. R.: Observational and model evidence for positive low-level cloud feedback, Science, 325, 460, https://doi.org/10.1126/science.1171255, 2009.

Collins, W. J., Bellouin, N., Doutriaux-Boucher, M., Gedney, N., Halloran, P., Hinton, T., Hughes, J., Jones, C. D., Joshi, M., Liddicoat, S., Martin, G., O’Connor, F., Rae, J., Senior, C., Sitch, S., Totterdell, I., Wiltshire, A., and Woodward, S.: Development and evaluation of an Earth-System model HadGEM2, Geosci. Model Dev., 4, 1051-1075, https://doi.org/10.5194/gmd-4-1051-2011, 2011

Dai, A., Trenberth, K. E., and Karl, T. R.: Effects of clouds, soil moisture, precipitation, and water vapor on diurnal temperature range, J. Climate, 12, 2451-2473, https://doi.org/10.1175/15200442(1999)012<2451:EOCSMP>2.0.CO;2, 1999.

De Bono, A., Peduzzi, P., Kluser, S., and Giuliani, G.: Impacts of summer 2003 heat wave in Europe, available at: https://www.unisdr.org/files/1145_ewheatwave.en.pdf (last access: 8 July 2020), 2004.

Dessler, A. E.: A determination of the cloud feedback from climate variations over the past decade, Science, 330, 1523-1527, https://doi.org/10.1126/science.1192546, 2010.

Dufresne, J.-L., Foujols, M.-A., Denvil, S., Caubel, A., Marti, O., Aumont, O., Balkanski, Y., Bekki, S., Bellenger, H., and Benshila, R.: Climate change projections using the IPSL-CM5 Earth
System Model: From CMIP3 to CMIP5, Clim. Dynam., 40, 2123-2165, https://doi.org/10.1007/s00382-012-1636-1, 2013.

Fischer, E. M., Seneviratne, S. I., Vidale, P. L., Lüthi, D., and Schär, C.: Soil moisture-atmosphere interactions during the 2003 European summer heat wave, J. Climate, 20, 5081-5099, https://doi.org/10.1175/JCLI4288.1, 2007.

Flato, G., Marotzke, J., Abiodun, B., Braconnot, P., Chou, S.-C., Collins, W., Cox, P., Driouech, F., Emori, S., Eyring, V., Forest, C., Gleckler, P., Guilyardi, E., Jakob, C., Kattsov, V., Reason, C., and Rummukainen, M.: Evaluation of climate models, in: Climate change 2013 - the physical science basis: Working group i contribution to the fifth assessment report of the Intergovernmental Panle on Climate Change, Cambridge University Press, Cambridge, UK and New York, USA, 741-866, 2013.

Gent, P. R., Danabasoglu, G., Donner, L. J., Holland, M. M., Hunke, E. C., Jayne, S. R., Lawrence, D. M., Neale, R. B., Rasch, P. J., and Vertenstein, M.: The Community Climate System Model version 4, J. Climate, 24, 4973-4991, https://doi.org/10.1175/2011JCLI4083.1, 2011.

Hansen, J., Sato, M., Nazarenko, L., Ruedy, R., Lacis, A., Koch, D., Tegen, I Hall, T., Shindell, D., Santer, B., Stone, P., Novakov, T., Thomason, L., Wang, R., Wang, Y., Jacob, D., Hollandsworth, S., Bishop, L., Logan, J., Thompson, A., Stolarski, R., Willson, R., Levitus, S., Antonov, J., Rayner, N., Parker, D., and Christy, J.: Climate forcings in Goddard Institute for Space Studies SI 2000 simulations, J. Geophys. Res.-Atmos., 107, D18, https://doi.org/10.1029/2001JD001143, 2002.

Hansen, J., Sato, M., Ruedy, R., Nazarenko, L., Lacis, A., Schmidt, G. A., Russell, G., Aleinov, I., Bauer, M., Bauer, S., Bell, N., Cairns, B., Canuto, V., Chandler, M., Cheng, Y., Del Genio, A., Faluvegi, G., Fleming, E., Friend, A., Hall, T., Jackman, C., Kelley, M., Kiang, N., Koch, D., Lean, J., Lerner, J., Lo, K., Menon, S., Miller, R., Minnis, P., Novakov, T., Oinas, V., Perlwitz, Ja., Perlwitz, Ju., Rind, D., Romanou, A., Shindell, D., Stone, P., Sun, S., Tausnev, N., Thresher, D., Wielicki, B., Wong, T., Yao, M., and Zhang, S.: Efficacy of climate forcings, J. Geophy. Res.-Atmos., 110, D18, https://doi.org/10.1029/2005JD005776, 2005.

Harrison, E. F., Minnis, P., Barkstrom, B. R., Ramanathan, V., Cess, R. D., and Gibson, G. G.: Seasonal-variation of cloud radiative forcing derived from the Earth Radiation Budget Experiment, J. Geophys. Res.-Atmos., 95, D11, 18687-18703, https://doi.org/10.1029/JD095iD11p18687, 1990.

Hurrell, J. W., Holland, M. M., Gent, P. R., Ghan, S., Kay, J. E., Kushner, P. J., Lamarque, J.-F., Large, W. G., Lawrence, D., and Lindsay, K.: The Community Earth System Model: A framework for collaborative research, B. Am. Meteorol. Soc., 94, 13391360, https://doi.org/10.1175/BAMS-D-12-00121.1, 2013.

Iversen, T., Bentsen, M., Bethke, I., Debernard, J. B., Kirkevåg, A., Seland, Ø., Drange, H., Kristjansson, J. E., Medhaug, I., Sand, M., and Seierstad, I. A.: The Norwegian Earth System Model, NorESM1-M - Part 2: Climate response and scenario projections, Geosci. Model Dev., 6, 389-415, https://doi.org/10.5194/gmd-6-389-2013, 2013.

Kay, J., Deser, C., Phillips, A., Mai, A., Hannay, C., Strand, G., Arblaster, J. M., Bates, S. C., Danabasoglu, G., and Edwards, J.: The Community Earth System Model (CESM) large ensemble project: A community resource for studying climate change in the presence of internal climate variability, B. Am. Meteo- 
rol. Soc., 96, 1333-1349, https://doi.org/10.1175/BAMS-D-13$00255.1,2015$.

Kirkevåg, A., Iversen, T., Seland, Ø., Hoose, C., Kristjánsson, J. E., Struthers, H., Ekman, A. M. L., Ghan, S., Griesfeller, J., Nilsson, E. D., and Schulz, M.: Aerosol-climate interactions in the Norwegian Earth System Model - NorESM1-M, Geosci. Model Dev., 6, 207-244, https://doi.org/10.5194/gmd-6-2072013, 2013.

Kjellstrom, T., Freyberg, C., Lemke, B., Otto, M., and Briggs, D.: Estimating population heat exposure and impacts on working people in conjunction with climate change, Int. J. Biometeorol., 62, 291-306, https://doi.org/10.1007/s00484-017-1407-0, 2018.

Koch, D. and Del Genio, A. D.: Black carbon semi-direct effects on cloud cover: review and synthesis, Atmos. Chem. Phys., 10, 7685-7696, https://doi.org/10.5194/acp-10-7685-2010, 2010.

Liu, L., Shawki, D., Voulgarakis, A., Kasoar, M., Samset, B. H., Myhre, G., Forster, P. M., Hodnebrog, Ø., Sillmann, J., Aalbergsjø, S. G., Boucher, O., Faluvegi, G., Iversen, T., Kirkeva ${ }^{\circ}$, A., Lamarque, J.-F., Olivié, D., Richardson, T., Shindell, D., and Takemura, T.: A PDRMIP multimodel study on the impacts of regional aerosol forcings on global and regional precipitation, J. Climate, 31, 4429-4447, https://doi.org/10.1175/jcli-d17-0439.1, 2018.

Lohmann, U. and Feichter, J.: Global indirect aerosol effects: a review, Atmos. Chem. Phys., 5, 715-737, https://doi.org/10.5194/acp-5-715-2005, 2005.

Mahajan, S., Evans, K. J., Hack, J. J., and Truesdale, J. E.: Linearity of climate response to increases in black carbon aerosols, J. Climate, 26, 8223-8237, https://doi.org/10.1175/JCLI-D-1200715.1, 2013.

Meehl, G. A., Arblaster, J. M., and Collins, W. D.: Effects of black carbon aerosols on the indian monsoon, J. Climate, 21, 28692882, https://doi.org/10.1175/2007jcli1777.1, 2008.

Menon, S., Hansen, J., Nazarenko, L., and Luo, Y.: Climate effects of black carbon aerosols in China and India, Science, 297, 22502253, https://doi.org/10.1126/science.1075159, 2002.

Myers, T. A. and Norris, J. R.: Observational evidence that enhanced subsidence reduces subtropical marine boundary layer cloudiness, J. Climate, 26, 7507-7524, https://doi.org/10.1175/JCLI-D-12-00736.1, 2013.

Myers, T. A., Mechoso, C. R., Cesana, G. V., DeFlorio, M. J., and Waliser, D. E.: Cloud feedback key to marine heatwave off Baja California, Geophys. Res. Lett., 45, 4345-4352, https://doi.org/10.1029/2018GL078242, 2018.

Myhre, G., Samset, B. H., Schulz, M., Balkanski, Y., Bauer, S., Berntsen, T. K., Bian, H., Bellouin, N., Chin, M., Diehl, T., Easter, R. C., Feichter, J., Ghan, S. J., Hauglustaine, D., Iversen, T., Kinne, S., Kirkevåg, A., Lamarque, J.-F., Lin, G., Liu, X., Lund, M. T., Luo, G., Ma, X., van Noije, T., Penner, J. E., Rasch, P. J., Ruiz, A., Seland, Ø., Skeie, R. B., Stier, P., Takemura, T., Tsigaridis, K., Wang, P., Wang, Z., Xu, L., Yu, H., Yu, F., Yoon, J.-H., Zhang, K., Zhang, H., and Zhou, C.: Radiative forcing of the direct aerosol effect from AeroCom Phase II simulations, Atmos. Chem. Phys., 13, 18531877, https://doi.org/10.5194/acp-13-1853-2013, 2013a.

Myhre, G., Shindell, D., Bréon, F.-M., Collins, W., Fuglestvedt, J., Huang, J., Koch, D., Lamarque, J.-F., Lee, D., Mendoza, B., Nakajima, T., Robock, A., Stephens, G., Takemura, T., and Zhang, H.: Anthropogenic and natural radiative forcing. in: Cli- mate change 2013: The physical science basis. Contribution of working group i to the fifth assessment report of the Intergovernmental Panel on Climate Change, edited by: Stoker, T. F., Qin, D., Plattner, G.-K., Tignor, M., Allen, S. K., Boschung, J., Nauels, A., Xia, Y., Bex, V., and Midgley, P. M., Cambridge University Press, Cambridge, UK and New York, USA, 659-740, 2013b.

Myhre, G., Forster, P., Samset, B., Hodnebrog, Ø., Sillmann, J., Aalbergsjø, S., Andrews, T., Boucher, O., Faluvegi, G., Fläschner, D., Iversen, T., Kasoar, M., Kharin, V., Kirkeväg, A., Lamarque, J.-F., Olivié, D., Richardson, T. B., Shindell, D., Shine, K., Stjern, C., Takemura, T., Voulgarakis, A., and Zwiers, F.: PDRMIP: A Precipitation Driver and Response Model Intercomparison Project, protocol and preliminary results, B. Am. Meteorol. Soc., 98, 1185-1198, https://doi.org/10.1175/BAMS-D-160019.1, 2017.

Neale, R. B., Richter, J. H., Conley, A. J., Park, S., Lauritzen, P. H., Gettelman, A., Williamson, D. L., Rasch, P. J., Vavrus, S. J., Taylor, M. A., Collins, W. D., Zhang, M., and Lin, S.-J.: Description of the NCAR community Atmosphere Model (CAM 4.0), available at Boulder, CO, USA: https://www.ccsm.ucar.edu/ models/ccsm4.0/cam/docs/description/cam4_desc.pdf (last access: 8 July 2020), 2010.

Otto-Bliesner, B. L., Brady, E. C., Fasullo, J., Jahn, A., Landrum, L., Stevenson, S., Rosenbloom, N., Mai, A., and Strand, G.: Climate variability and change since $850 \mathrm{CE}$ : An ensemble approach with the Community Earth System Model, B. Am. Meteorol. Soc., 97, 735-754, https://doi.org/10.1175/BAMS-D-14-00233.1, 2016.

Paaijmans, K. P., Blanford, S., Bell, A. S., Blanford, J. I., Read, A. F., and Thomas, M. B.: Influence of climate on malaria transmission depends on daily temperature variation, P. Natl. Acad. Sci. USA, 107, 15135, https://doi.org/10.1073/pnas.1006422107, 2010.

Philipona, R., Behrens, K., and Ruckstuhl, C.: How declining aerosols and rising greenhouse gases forced rapid warming in Europe since the 1980s, Geophys. Res. Lett., 36, L02806, https://doi.org/10.1029/2008GL036350, 2009.

Ramanathan, V., Cess, R. D., Harrison, E. F., Minnis, P., Barkstrom, B. R., Ahmad, E., and Hartmann, D.: Cloudradiative forcing and climate: Results from the Earth Radiation Budget Experiment, Science, 243, 57-63, https://doi.org/10.1126/science.243.4887.57, 1989.

Robine, J.-M., Cheung, S. L. K., Le Roy, S., Van Oyen, H., Griffiths, C., Michel, J.-P., and Herrmann, F. R.: Death toll exceeded 70000 in Europe during the summer of 2003, C. R. Biol., 331, 171-178, https://doi.org/10.1016/j.crvi.2007.12.001, 2008.

Rowell, D. P. and Jones, R. G.: Causes and uncertainty of future summer drying over Europe, Clim. Dynam., 27, 281-299, https://doi.org/10.1007/s00382-006-0125-9, 2006.

Ruckstuhl, C., Philipona, R., Behrens, K., Collaud Coen, M., Dürr, B., Heimo, A., Mätzler, C., Nyeki, S., Ohmura, A., Vuilleumier, L., Weller, M., Wehrli, C., and Zelenka, A.: Aerosol and cloud effects on solar brightening and the recent rapid warming, Geophys. Res. Lett., 35, L12708, https://doi.org/10.1029/2008GL034228, 2008.

Samset, B. H. and Myhre, G.: Climate response to externally mixed black carbon as a function of altitude, J. Geophys. Res.-Atmos., 120, 2913-2927, https://doi.org/10.1002/2014JD022849, 2015. 
Samset, B., Myhre, G., Forster, P., Hodnebrog, Ø., Andrews, T., Faluvegi, G., Fläschner, D., Kasoar, M., Kharin, V., Kirkevåg, A., Lamarque, J.-F., Olivié, D., Richardson, T., Shindell, D., Shine, K. P., Takemura, T., and Voulgarakis, A.: Fast and slow precipitation responses to individual climate forcers: A PDRMIP multimodel study, Geophys. Res. Lett., 43, 2782-2791, https://doi.org/10.1002/2016GL068064, 2016.

Schär, C., Vidale, P. L., Lüthi, D., Frei, C., Häberli, C., Liniger, M. A., and Appenzeller, Christof: The role of increasing temperature variability in European summer heatwaves, Nature, 427, 332-336, https://doi.org/10.1038/nature02300, 2004.

Schmidt, G. A., Kelley, M., Nazarenko, L., Ruedy, R., Russell, G. L., Aleinov, I., Bauer, M., Bauer, S. E., Bhat, M. K., and Bleck, R.: Configuration and assessment of the GISS ModelE2 contributions to the CMIP5 archive, J. Adv. Model. Earth Sy., 6, 141-184, https://doi.org/10.1002/2013MS000265, 2014.

Seidel, D. J., Fu, Q., Randel, W. J., and Reichler, T. J.: Widening of the tropical belt in a changing climate, Nat. Geosci., 1, 21-24, https://doi.org/10.1038/ngeo.2007.38, 2008.

Seneviratne, S. I., Luthi, D., Litschi, M., and Schar, C.: Landatmosphere coupling and climate change in Europe, Nature, 443, 205-209, https://doi.org/10.1038/nature05095, 2006.

Seneviratne, S. I., Donat, M. G., Mueller, B., and Alexander, L. V.: No pause in the increase of hot temperature extremes, Nat. Clim. Change, 4, 161, https://doi.org/10.1038/nclimate2145, 2014.

Shindell, D. and Faluvegi, G.: Climate response to regional radiative forcing during the twentieth century, Nat. Geosci., 2, 294-300, https://doi.org/10.1038/Ngeo473, 2009.

Sillmann, J., Pozzoli, L., Vignati, E., Kloster, S., and Feichter, J.: Aerosol effect on climate extremes in Europe under different future scenarios, Geophys. Res. Lett., 40, 2290-2295, https://doi.org/10.1002/grl.50459, 2013.

Smith, S. J., van Aardenne, J., Klimont, Z., Andres, R. J., Volke, A., and Delgado Arias, S.: Anthropogenic sulfur dioxide emissions: 1850-2005, Atmos. Chem. Phys., 11, 1101-1116, https://doi.org/10.5194/acp-11-1101-2011, 2011.

Stjern, C. W., Samset, B. H., Myhre, G., Forster, P. M., Hodnebrog, O., Andrews, T., Boucher, O., Faluvegi, G., Iversen, T., Kasoar, M., Kharin, V., Kirkevag, A., Lamarque, J. F., Olivie, D., Richardson, T., Shawki, D., Shindell, D., Smith, C. J., Takemura, T., ad Voulgarakis, A.: Rapid adjustments cause weak surface temperature response to increased black carbon concentrations, J. Geophys. Res.-Atmos., 122, 11462-11481, https://doi.org/10.1002/2017jd027326, 2017.

Takemura, T., Nozawa, T., Emori, S., Nakajima, T. Y., and Nakajima, T.: Simulation of climate response to aerosol direct and indirect effects with aerosol transport-radiation model, J. Geophys. Res.-Atmos., 110, D2, https://doi.org/10.1029/2004JD005029, 2005.

Takemura, T., Egashira, M., Matsuzawa, K., Ichijo, H., O’ishi, R., and Abe-Ouchi, A.: A simulation of the global distribution and radiative forcing of soil dust aerosols at the Last Glacial Maximum, Atmos. Chem. Phys., 9, 3061-3073, https://doi.org/10.5194/acp-9-3061-2009, 2009.

Tang, Q. and Leng, G.: Damped summer warming accompanied with cloud cover increase over Eurasia from 1982 to 2009, Environ. Res. Lett., 7, 014004, https://doi.org/10.1088/17489326/7/1/014004, 2012.
Tang, T., Shindell, D., Samset, B. H., Boucher, O., Forster, P. M., Hodnebrog, Ø., Myhre, G., Sillmann, J., Voulgarakis, A., Andrews, T., Faluvegi, G., Fläschner, D., Iversen, T., Kasoar, M., Kharin, V., Kirkevåg, A., Lamarque, J.-F., Olivié, D., Richardson, T., Stjern, C. W., and Takemura, T.: Dynamical response of Mediterranean precipitation to greenhouse gases and aerosols, Atmos. Chem. Phys., 18, 8439-8452, https://doi.org/10.5194/acp-18-8439-2018, 2018.

Tang, T., Shindell, D., Faluvegi, G., Myhre, G., Olivié, D., Voulgarakis, A., Kasoar, M., Andrews, T., Boucher, O., Forster, P. M., Hodnebrog, Ø., Iversen, T., Kirkevåg, A., Lamarque, J. F., Richardson, T., Samset, B. H., Stjern, C. W., Takemura, T., and Smith, C.: Comparison of effective radiative forcing calculations using multiple methods, drivers, and models, J. Geophys. Res.-Atmos., 124, 4382-4394, https://doi.org/10.1029/2018JD030188, 2019.

Turner, A. G. and Annamalai, H.: Climate change and the South Asian summer monsoon, Nat. Clim. Change, 2, 587-595, https://doi.org/10.1038/nclimate1495, 2012.

Vasseur David, A., DeLong John, P., Gilbert, B., Greig, H. S., Harley, D. G., McCann, K. S., Savage, V., Tunney, T. D., and O'Connor, M. I.: Increased temperature variation poses a greater risk to species than climate warming, P. Roy. Soc B 281, 20132612, https://doi.org/10.1098/rspb.2013.2612, 2014.

Vautard, R., Yiou, P., D’Andrea, F., de Noblet, N., Viovy, N., Cassou, C., Polcher, J., Ciais, P., Kageyama, M., and Fan, Y.: Summertime European heat and drought waves induced by wintertime Mediterranean rainfall deficit, Geophys. Res. Lett., 34, L07711, https://doi.org/10.1029/2006GL028001, 2007.

Walters, D. N., Williams, K. D., Boutle, I. A., Bushell, A. C., Edwards, J. M., Field, P. R., Lock, A. P., Morcrette, C. J., Stratton, R. A., Wilkinson, J. M., Willett, M. R., Bellouin, N., Bodas-Salcedo, A., Brooks, M. E., Copsey, D., Earnshaw, P. D., Hardiman, S. C., Harris, C. M., Levine, R. C., MacLachlan, C., Manners, J. C., Martin, G. M., Milton, S. F., Palmer, M. D., Roberts, M. J., Rodríguez, J. M., Tennant, W. J., and Vidale, P. L.: The Met Office Unified Model Global Atmosphere 4.0 and JULES Global Land 4.0 configurations, Geosci. Model Dev., 7, 361-386, https://doi.org/10.5194/gmd-7-361-2014, 2014.

Wang, C.: Impact of direct radiative forcing of black carbon aerosols on tropical convective precipitation, Geophys. Res. Lett., 34, L05709, https://doi.org/10.1029/2006GL028416, 2007.

Wang, G. and Dillon, M. E.: Recent geographic convergence in diurnal and annual temperature cycling flattens global thermal profiles, Nat. Clim. Change, 4, 988-992, https://doi.org/10.1038/Nclimate2378, 2014.

Watanabe, M., Suzuki, T., O'ishi, R., Komuro, Y., Watanabe, S., Emori, S., Takemura, T., Chikira, M., Ogura, T., and Sekiguchi, M.: Improved climate simulation by MIROC5: Mean states, variability, and climate sensitivity, J. Climate, 23, 6312-6335, https://doi.org/10.1175/2010JCLI3679.1, 2010.

Wetherald, R. T. and Manabe, S.: The mechanisms of summer dryness induced by greenhouse warming, J. Climate, 8, 3096-3108, https://doi.org/10.1175/15200442(1995)008<3096:TMOSDI>2.0.CO;2, 1995.

Wild, M., Ohmura, A., Gilgen, H., and Rosenfeld, D.: On the consistency of trends in radiation and temperature records and implications for the global hydrological cycle, Geophys. Res. Lett., 31, https://doi.org/10.1029/2003GL019188, 2004. 
Williams, K. D., Jones, A., Roberts, D. L., Senior, C. A., and Woodage, M. J.: The response of the climate system to the indirect effects of anthropogenic sulfate aerosol, Clim. Dynam., 17, 845-856, https://doi.org/10.1007/s003820100150, 2001.

Wood, R. and Bretherton, C. S.: On the relationship between stratiform low cloud cover and lower-tropospheric stability, J. Climate, 19, 6425-6432, https://doi.org/10.1175/JCLI3988.1, 2006.

$\mathrm{Xu}$, Y. Y., Lamarque, J. F., and Sanderson, B. M.: The importance of aerosol scenarios in projections of future heat extremes, Climatic Change, 146, 393-406, https://doi.org/10.1007/s10584015-1565-1, 2018.

Zampieri, M., D'Andrea, F., Vautard, R., Ciais, P., de Noblet-Ducoudré, N., and Yiou, P.: Hot European summers and the role of soil moisture in the propagation of Mediterranean drought, J. Climate, 22, 4747-4758, https://doi.org/10.1175/2009JCLI2568.1, 2009.
Zelinka, M. D., Randall, D. A., Webb, M. J., and Klein, S. A.: Clearing clouds of uncertainty, Nat. Clim. Change, 7, 674-678, https://doi.org/10.1038/nclimate3402, 2017.

Zhai, C. X., Jiang, J. H., and Su, H.: Long-term cloud change imprinted in seasonal cloud variation: More evidence of high climate sensitivity, Geophys. Res. Lett., 42, 8729-8737, https://doi.org/10.1002/2015gl065911, 2015.

Zhou, C., Zelinka, M. D., and Klein, S. A.: Impact of decadal cloud variations on the earth's energy budget, Nat. Geosci., 9, 871, https://doi.org/10.1038/ngeo2828, 2016. 